\title{
DÜBLIN
}

Technological University Dublin

ARROW@TU Dublin

\section{The effect of non-thermal plasma on the lipid oxidation and microbiological quality of sushi}

\author{
Piotr Kulawik \\ University of Agriculture, Krakow \\ Carlos Alvarez \\ Teagasc Food Research Centre \\ Patrick J. Cullen \\ Technological University Dublin, patrick.j.cullen@tudublin.ie
}

See next page for additional authors

Follow this and additional works at: https://arrow.tudublin.ie/schfsehart

Part of the Food Science Commons, and the Medicine and Health Sciences Commons

\section{Recommended Citation \\ Piotr Kulawik, Carlos Alvarez, Patrick J. Cullen, Ramon Aznar-Roca, Anne Maria Mullen, Brijesh Tiwari, The effect of non-thermal plasma on the lipid oxidation and microbiological quality of sushi, Innovative Food Science \& Emerging Technologies, Volume 45, 2018, Pages 412-417, ISSN 1466-8564, DOI: 10.1016/ j.ifset.2017.12.011.}

This Article is brought to you for free and open access by the School of Food Science and Environmental Health at ARROW@TU Dublin. It has been accepted for inclusion in Articles by an authorized administrator of ARROW@TU Dublin. For more information, please contact arrow.admin@tudublin.ie, aisling.coyne@tudublin.ie, gerard.connolly@tudublin.ie.

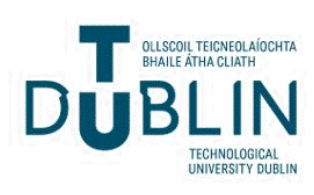




\section{Authors}

Piotr Kulawik, Carlos Alvarez, Patrick J. Cullen, Ramon Aznar-Roca, Anne Maria Mullen, and Brijesh Tiwari 


\title{
The effect of non-thermal plasma on the lipid oxidation and microbiological quality of sushi
}

\author{
Piotr Kulawik ${ }^{\mathrm{a}, *}$, Carlos Alvarez ${ }^{\mathrm{b}}$, Patrick J. Cullen ${ }^{\mathrm{c}}$, Ramon Aznar-Roca ${ }^{\mathrm{d}}$, Anne Maria Mullen ${ }^{\mathrm{b}}$, \\ Brijesh Tiwari $^{\mathrm{d}}$
}

${ }^{a}$ Department of Animal Product Technology, Faculty of Food Technology, University of Agriculture, Krakow, Poland

${ }^{\mathrm{b}}$ Department of Food Quality and Sensory Science, Teagasc Food Research Centre, Ashtown, Dublin, Ireland

c Dublin Institute of Technology, Dublin, Ireland

${ }^{\mathrm{d}}$ Department of Food Biosciences, Teagasc Food Research Centre, Ashtown, Dublin, Ireland

\section{A R T I C L E I N F O}

\section{Keywords:}

Sushi

Non-thermal plasma

Lipid oxidation

Microbiological quality

Nigiri

Maki

\begin{abstract}
A B S T R A C T
The study examined the effect of non-thermal plasma (NTP) on the total viable count and lipid oxidation of two common sushi products: nigiri and hosomaki. Sushi samples were treated with NTP using a dielectric barrier discharge system with 70 and $80 \mathrm{kV}$ of potential differences for $5 \mathrm{~min}$. The samples were stored at $4{ }^{\circ} \mathrm{C}$ for 11 days and analysed for total aerobic count, moisture and protein content, TBA index and fatty acids composition. Although the effect of NTP on the total aerobic counts was not statistically significant, a tendency in log reduction could be observed, with 1-1.5 log cfu/g reduction. Moisture and protein content, as well as fatty acids composition of sushi was not affected by the treatment. The TBA index of treated samples increased significantly by $0.4-1.5 \mathrm{mg} / \mathrm{kg}$, with hosomaki reaching higher TBA index than nigiri. Although NTP in the studied conditions can, to a limited degree, increase the microbiological quality of the sushi samples, it also increases the oxidation rate.
\end{abstract}

\section{Introduction}

Globally there is a growing trend for the consumption of ready-toeat (RTE) sushi meals. According to Altintzoglou, Heide, Wien, and Honkanen (2016) consumers from Norway and Japan purchase RTE sushi meals 0.47 and 1.75 times per week, respectively, and the Norwegian Seafood Council reports that $18 \%$ of Germans who frequently consume sushi, purchase it in the form of a RTE meal from supermarket (NSC, 2015).

RTE sushi meal producers are challenged by the short shelf-life of their product, with microbiological spoilage and rice retrogradation being one of the main factors affecting the product's shelf-life. Sushi contains raw fish and seafood, therefore the bacterial concentration cannot be reduced using thermal treatments and the use of preservatives is typically not employed due to the desire from consumers for a product with a 'clean label' classification (Don, 1997). Moreover not all minimal processing techniques, however, can be implemented into sushi processing. For example high-pressure processing (HPP), can be used to effectively reduce microbiological counts and browning for avocado (Jacobo-Velázquez \& Hernández-Brenes, 2010; López-Malo, Palou, Barbosa-Cánovas, Welti-Chanes, \& Swanson, 1998), an important sushi ingredient, but cannot be used for many unprocessed fish species, including salmon, since it can cause changes in physicochemical properties such as color and texture (S. Zhu, Ramaswamy, \& Simpson, 2004), and increase lipid oxidation and free fatty acids formation (Sequeira-Munoz, Chevalier, LeBail, Ramaswamy, \& Simpson, 2006). Processing techniques which are used in sushi processing, include modified atmosphere packaging (MAP), and treatment with ozone, electrolyzed water, ultrasound and UV radiation. Those methods can be used separately or in combination, however, the highest noted shelf-life improvement was from 3 to 7 days (Steffen, Duerst, \& Rice, 2010); nevertheless, using the combination of all those methods requires high investment and maintenance costs.

Starch retrogradation is a process in which amylose and amylopectin chains, disrupted during thermal treatment in the presence of water, reassociate creating different crystalline structures. This results in texture changes and might affect the sensory parameters and consumer acceptance of the final product (Wang, Li, Copeland, Niu, \& Wang, 2015). Starch retrogradation can be divided into short-term and long-term retrogradation. The first appears usually within hours up to 2 days of storage, and is caused by recrystallization of amylose, while the latter might last several weeks and is caused by formation of

\footnotetext{
* Corresponding author at: Department of Animal Products Technology, Faculty of Food Technology, University of Agriculture, ul. Balicka 122, 30-149 Cracow, Poland.

E-mail address: p.kulawik@ur.krakow.pl (P. Kulawik).
} 
amylopectin crystals around the crystal nuclei formed by amylose (Fu, Chen, Luo, Liu, \& Liu, 2015). Rice starch retrogradation decreases sensory properties and consumer acceptance (Kwak, Kim, \& Jeong, 2015) which in turn affects shelf-life of stored RTE sushi meals.

Non-thermal plasma (NTP) is a novel preservation method in which the treated product is exposed to a direct plasma discharge or its afterglow (gas reactive species). Decontamination of the product's surface can result from action of reactive species (RS) and UV radiation (Boudam et al., 2006; Ehlbeck et al., 2011; Moreau, Orange, \& Feuilloley, 2008). The exact type of formed RS depends on the atmosphere used to form the plasma which for atmospheric air includes reactive oxygen species, reactive nitrogen species, excited oxygen and nitrogen, hydrogen peroxide, $\mathrm{OH}$ radicals, $\mathrm{H}_{2} \mathrm{O}^{+}$and $\mathrm{OH}^{-}$ions (Scholtz, Pazlarova, Khun, \& Julak, 2015). Non-thermal plasmas have demonstrated efficacy for various food pathogens, including Escherichia coli, Staphylococcus aureus or Bacillus cereus achieving reduction rates of up to $7 \mathrm{log} \mathrm{cfu} / \mathrm{g}$ (Ehlbeck et al., 2011). Any associated increase in the temperature of the treated surface is limited (Fridman et al., 2007) which suggests that non-thermal plasma could be effectively used to increase the shelf-life of sushi products. Conversely, NTP can increase lipid oxidation in complex food matrices (Van Durme, Nikiforov, Vandamme, Leys, \& De Winne, 2014), and might not be suitable for food products containing high levels of unsaturated fatty acids, such as fish (Misra, Tiwari, Raghavarao, \& Cullen, 2011) or sushi. To date there is no data which would allow establishing whether NTP can be a suitable method for prolonging the shelf-life of sushi. Therefore the aim of this study was to establish the effect of NTP on the bacterial concentration and lipid oxidation of two common sushi products: nigiri and hosomaki, using a dielectric barrier discharge (DBD) system with two different electric potential differences: 70 and $80 \mathrm{kV}$.

\section{Materials and methods}

\subsection{Materials}

Sushi rice (Oryza sativa japonica), nori (dried Porphyra tenera sheets), rice vinegar, sugar and salt were acquired from the local market located in Dublin, Ireland. Salmon (Salmo salar) was cultivated, slaughtered, filleted and skinned by an Irish fish processor and skinless fillets were purchased from local fishmonger located in Dublin, Ireland. The fillets were transported for $15 \mathrm{~min}$ in ice to food production laboratories located in Teagasc Food Research Centre (Ashtown, Dublin, Ireland) and immediately used for sushi production. The total time from fish slaughter through to sushi production was 4 days.

\subsection{Sushi production}

Sushi rice was washed in running water for $5 \mathrm{~min}$ and left to drain for an additional $5 \mathrm{~min}$. Next the rice was transferred to Gastronorm sizes (GN) containers with covers, mixed with water using $0.8: 1 \mathrm{w} / \mathrm{w}$ ratio and placed in convection oven (Rational SCC 61, Rational AG, Landsberg am Lech, Germany) for $55 \mathrm{~min}$ at $110^{\circ} \mathrm{C}$ with $100 \%$ humidity. Afterwards the rice was mixed with vinegar mixture (rice vinegar, sucrose, salt in ratio of 0.52:0.42:0.06 w/w/w) using ratio of $1: 0.125 \mathrm{v} / \mathrm{v}$, gently stirred with taking special care not to damage the grains and left to cool down to temperature of $40{ }^{\circ} \mathrm{C}$.

Nigiri-sushi was produced by forming $20 \mathrm{~g}( \pm 0.5 \mathrm{~g})$ rice balls and placing a rhomboid shaped salmon piece weighing $12 \mathrm{~g}( \pm 0.1 \mathrm{~g})$ on top of it. All nigiri samples contained approximately $37.5 \%$ of raw salmon.

Hosomaki was produced by placing $90 \mathrm{~g}$ of sushi rice and $20 \mathrm{~g}$ of salmon strip on a half of a nori sheet $(1.5 \mathrm{~g})$ and wrapping it using a bamboo mat into a thin circular roll. The rolls were then cut into eight equal pieces (approx. 13.5-14.0 g per piece). All hosomaki samples contained approximately $17.9 \%$ of raw salmon.

Each piece of nigiri and maki were placed separately into $80 \mathrm{~mm}$ round polyethylene terephthalate (PET) containers and sealed in air using traysealer machine (Olympus, Italian Pack, Como, Italy).

\subsection{Plasma treatment}

Plasma was generated using a dielectric barrier discharge system, as described by Misra et al. (2014). PET containers containing sushi samples were placed between two $158 \mathrm{~mm}$ diameter aluminium disc electrodes with two polypropylene dielectrics - $10 \mathrm{~mm}$ thick acrylic glass used at the high voltage electrode and $2 \mathrm{~mm}$ thick polypropylene at the ground electrode. The distance between the electrodes was $52 \mathrm{~mm}$ (height of the container plus the dielectrics thickness). Previous tests were performed to establish the most adequate treatment time (data not shown). Sushi samples were stored in ice and treated for 1, 3, 5 and $10 \mathrm{~min}$ with 70 and $80 \mathrm{kV}$ discreet voltages generated by high voltage step-up transformer (Phoenix Technologies Inc., Accident, MD, USA) at $50 \mathrm{~Hz}$ frequency. Afterwards, the samples were stored for 1 day and analysed for total viable count (as per method described in Section 2.4). Based on the results of the preliminary analysis the shortest, most effective treatment time was chosen to be $5 \mathrm{~min}$ of plasma treatment. The sushi samples used for all subsequent analyses were treated in the same manner as in preliminary tests but with only $5 \mathrm{~min}$ as a treatment time. After the plasma treatment the samples were stored at $4{ }^{\circ} \mathrm{C}$ until subsequent analysis.

\subsection{Microbiological analysis}

The analysis of total viable count (TVC) was performed according to ISO standard no. 4833-1:2013 with a slight modification related to the amount of sample used. In case of nigiri exactly $6.25 \mathrm{~g}$ of rice and $3.75 \mathrm{~g}$ of salmon from each nigiri was homogenized with $90 \mathrm{~g}$ of maximum recovery diluent (Sigma-Aldrich, Saint Louis, MO, USA). In case of hosomaki, a whole hosomaki piece (13.5-14.0 g) was homogenized with maximum recovery diluent in ratio of 1:9. The homogenization was carried out using Stomacher device for 2 min followed by preparation of appropriate decimal dilutions. The analysis was performed by the pour plate method, using plate count agar (Sigma-Aldrich). The plates were incubated at $30^{\circ} \mathrm{C}$ for $48 \mathrm{~h}$.

The microbiological analysis was performed on day 1, 3, 5, 8 and 11 of storage at $4{ }^{\circ} \mathrm{C}$ and the results were expressed as log cfu/g of sushi sample.

\subsection{TBA analysis}

The 2-thiobarbituric acid (TBA) index analysis was performed according to the aqueous extraction method described by Pikul, Leszczynski, and Kummerow (1989). The sample was homogenized until reaching uniformity and then $10 \mathrm{~g}$ was measured and homogenized with $34.25 \mathrm{ml}$ of $4 \%$ perchloric acid and $0.75 \mathrm{ml}$ of butylated hydroxytoluene (BHT), filtered through Whatman no. 1 filter paper (Whatman PLC, Maidstone, UK) and adjusted to $50 \mathrm{ml}$ using $4 \%$ perchloric acid. Five milliter of filtrate was transferred into glass tubes containing $5 \mathrm{ml}$ of $0.02 \mathrm{M} \mathrm{TBA}$ and heated at $90^{\circ} \mathrm{C}$ for $1 \mathrm{~h}$ in water bath. After heating the tubes were cooled with tap water until reaching room temperature and measured for absorbance at $532 \mathrm{~nm}$ wavelength using Helios Gamma spectrophotometer (Thermo Fisher Scientific, Essex, UK). The blank sample was prepared in the same manner as the normal samples except $5 \mathrm{ml}$ of $4 \%$ perchloric acid was used instead of filtrate. The constant coefficient $\mathrm{K}$, used for calculating the thiobarbituric acid reactive substances (TBARS) content, was calculated from the standard curve.

The TBA analysis was performed on sushi samples on day 1, 3, 5 and 8 of storage. The analysis of nigiri samples on day 11 was not performed due to high microbiological spoilage of the samples. 
Table 1

Changes in total viable count of treated and untreated nigiri and hosomaki samples during storage $[\log \mathrm{cfu} / \mathrm{g}]$.

\begin{tabular}{|c|c|c|c|c|c|}
\hline & Day 1 & Day 3 & Day 5 & Day 8 & Day 11 \\
\hline Nigiri Control & $5.96^{\mathrm{aA}} \pm 0.62$ & $6.80^{\mathrm{aA}} \pm 0.92$ & $8.34^{\mathrm{bA}} \pm 0.15$ & $9.06^{\mathrm{bA}} \pm 0.02$ & $9.01^{\mathrm{bA}} \pm 0.17$ \\
\hline Nigiri $70 \mathrm{kV}$ & $4.98^{\mathrm{aA}} \pm 0.50$ & $6.50^{\mathrm{bA}} \pm 0.14$ & $7.77^{\mathrm{cA}} \pm 0.65$ & $8.63^{\mathrm{cA}} \pm 0.51$ & $8.99^{\mathrm{cA}} \pm 0.32$ \\
\hline Nigiri $80 \mathrm{kV}$ & $4.83^{\mathrm{aA}} \pm 0.37$ & $6.28^{\mathrm{bA}} \pm 0.23$ & $7.57^{\mathrm{cA}} \pm 0.25$ & $9.14^{\mathrm{dA}} \pm 0.90$ & $9.16^{\mathrm{dA}} \pm 0.38$ \\
\hline Hosomaki Control & $4.38^{\mathrm{aA}} \pm 0.66$ & $4.94^{\mathrm{aA}} \pm 0.57$ & $4.83^{\mathrm{aA}} \pm 0.79$ & $6.65^{\mathrm{aA}} \pm 2.05$ & $6.22^{\mathrm{aA}} \pm 1.90$ \\
\hline Hosomaki $70 \mathrm{kV}$ & $4.90^{\mathrm{aA}} \pm 0.45$ & $4.21^{\mathrm{aA}} \pm 0.78$ & $3.85^{\mathrm{aA}} \pm 1.00$ & $5.79^{\mathrm{aA}} \pm 1.46$ & $4.71^{\mathrm{aA}} \pm 0.51$ \\
\hline Hosomaki $80 \mathrm{kV}$ & $4.39^{\mathrm{aA}} \pm 0.73$ & $4.50^{\mathrm{aA}} \pm 1.06$ & $4.14^{\mathrm{aA}} \pm 0.99$ & $5.14^{\mathrm{aA}} \pm 0.32$ & $5.26^{\mathrm{aA}} \pm 0.43$ \\
\hline
\end{tabular}

a,b,c,d - different lowercase in a row indicate differences between days of storage within the same group $(P<0.05)$.

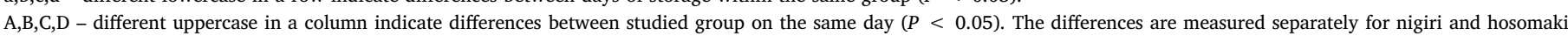
groups.

Table 2

Changes in proximate composition $[\mathrm{g} / 100 \mathrm{~g}]$ over 8 day storage period at $4{ }^{\circ} \mathrm{C}$.

\begin{tabular}{|c|c|c|c|c|}
\hline & Day 1 & Day 3 & Day 5 & Day 8 \\
\hline \multicolumn{5}{|l|}{ Moisture } \\
\hline Nigiri control & $67.49^{\mathrm{aA}} \pm 1.60$ & $66.66^{\mathrm{aA}} \pm 1.38$ & $67.51^{\mathrm{aA}} \pm 3.04$ & $66.58^{\mathrm{aA}} \pm 1.32$ \\
\hline Nigiri $70 \mathrm{kV}$ & $65.68^{\mathrm{aA}} \pm 1.52$ & $66.17^{\mathrm{aA}} \pm 1.16$ & $67.65^{\mathrm{aA}} \pm 0.95$ & $66.80^{\mathrm{aA}} \pm 0.93$ \\
\hline Nigiri 80 kV & $67.17^{\mathrm{aA}} \pm 1.15$ & $66.73^{\mathrm{aA}} \pm 3.28$ & $67.09^{\mathrm{aA}} \pm 0.07$ & $67.20^{\mathrm{aA}} \pm 1.65$ \\
\hline Hosomaki control & $63.61^{\mathrm{aA}} \pm 1.53$ & $63.90^{\mathrm{aA}} \pm 0.27$ & $64.58^{\mathrm{aA}} \pm 1.86$ & $63.32^{\mathrm{aA}} \pm 1.30$ \\
\hline Hosomaki 70 kV & $65.25^{\mathrm{aA}} \pm 0.24$ & $63.83^{\mathrm{aA}} \pm 1.63$ & $63.71^{\mathrm{aA}} \pm 1.30$ & $62.63^{\mathrm{aA}} \pm 0.46$ \\
\hline Hosomaki $80 \mathrm{kV}$ & $64.49^{\mathrm{aA}} \pm 1.24$ & $64.18^{\mathrm{aA}} \pm 1.86$ & $64.52^{\mathrm{aA}} \pm 0.64$ & $64.54^{\mathrm{aA}} \pm 1.40$ \\
\hline \multicolumn{5}{|l|}{ Protein } \\
\hline Nigiri control & $8.93^{\mathrm{aA}} \pm 0.59$ & $9.36^{\mathrm{aA}} \pm 0.19$ & $8.50^{\mathrm{aA}} \pm 1.17$ & $9.04^{\mathrm{aA}} \pm 0.67$ \\
\hline Nigiri 70 kV & $10.10^{\mathrm{aA}} \pm 0.20$ & $8.84^{\mathrm{aA}} \pm 0.18$ & $8.19^{\mathrm{aA}} \pm 1.13$ & $8.84^{\mathrm{aA}} \pm 0.91$ \\
\hline Nigiri $80 \mathrm{kV}$ & $9.58^{\mathrm{aA}} \pm 0.93$ & $9.44^{\mathrm{aA}} \pm 0.65$ & $8.73^{\mathrm{aA}} \pm 1.21$ & $9.47^{\mathrm{aA}} \pm 1.35$ \\
\hline Hosomaki control & $5.54^{\mathrm{aA}} \pm 0.73$ & $5.51^{\mathrm{aA}} \pm 0.52$ & $5.38^{\mathrm{aA}} \pm 0.79$ & $6.14^{\mathrm{aA}} \pm 0.23$ \\
\hline Hosomaki 70 kV & $6.15^{\mathrm{aA}} \pm 0.68$ & $6.07^{\mathrm{aA}} \pm 0.65$ & $5.33^{\mathrm{aA}} \pm 0.47$ & $6.18^{\mathrm{aA}} \pm 0.27$ \\
\hline Hosomaki $80 \mathrm{kV}$ & $6.06^{\mathrm{aA}} \pm 0.60$ & $6.73^{\mathrm{aA}} \pm 0.37$ & $5.24^{\mathrm{aA}} \pm 0.56$ & $6.31^{\mathrm{aA}} \pm 0.35$ \\
\hline
\end{tabular}

Results expressed as mean \pm standard deviation.

a,b - different lowercase in a row indicate differences between days of storage within the same group $(P<0.05)$.

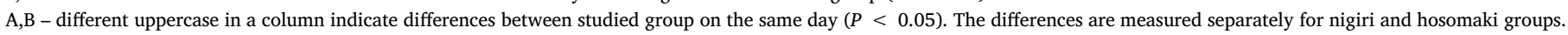

\subsection{Protein, moisture and fatty acids analysis}

Each sample was homogenized until reaching uniform distribution of all the ingredients and then used for subsequent analysis.

Protein content was determined based on the measurement of nitrogen by combustion using a LECO FP628 Protein analyzer (LECO Corp., MI, USA) based on the Dumas method according to the AOAC method 992.15 (2007). A factor of 6.25 was used to convert nitrogen to crude protein per cent. Moisture content were measured using a Smart System 5 microwave drying oven (Smart Trac 5 Model 907,875, CEM Corporation, NC, USA) using AOAC Official Methods no. 985.16 (2007).

The fat for fatty acids analysis was extracted using the method described by Bligh and Dyer (1959) and the methylation procedure was performed as described by Ichihara, Shibahara, Yamamoto, and Nakayama (1996). Fatty acids were extracted by mixing $1 \mathrm{~g}$ of the sample with $10 \mathrm{ml}$ of hexane. The mixture was stirred for $1 \mathrm{~h}$ and after a centrifugation step ( $2000 \mathrm{~g}$ for $10 \mathrm{~min}$ ) a clear supernatant was collected. This step was repeated three times. The hexane from the three extractions was pooled and evaporated under nitrogen stream and the weight of remaining fat was measured. After this, fatty acid profile analysis was carried out. Samples were analysed using an Agilent 7890A gas chromatography system coupled to an Agilent 5975C mass spectrometer (Agilent Technologies, Cheshire, UK). Samples $(0.5 \mu \mathrm{l})$ were injected onto the GC/MS system via an Agilent 7963 autosampler (Agilent Technologies, Cheshire, UK), where separation was achieved using a Phenomenex BPX70 column $(120 \mathrm{~m} \times 0.25 \mathrm{~mm}, 0.25 \mu \mathrm{m})$. The initial temperature of each run was $50{ }^{\circ} \mathrm{C}$, which was ramped to $160{ }^{\circ} \mathrm{C}$ $\left(20^{\circ} \mathrm{C} / \mathrm{min}\right)$, followed by a further increase in temperature to $220^{\circ} \mathrm{C}$ $\left(4{ }^{\circ} \mathrm{C} / \mathrm{min}\right.$ ) and held for $5 \mathrm{~min}$. Afterwards a final increase to $240{ }^{\circ} \mathrm{C}$ $\left(4{ }^{\circ} \mathrm{C} / \mathrm{min}\right.$ ) was carried out, and held for $13 \mathrm{~min}$. The inlet temperature was set at $250^{\circ} \mathrm{C}$, while hydrogen was used as the carrier gas $(2 \mathrm{ml}$ / min). Fatty acids were injected in full SCAN and SIM at the same time after derivatization. The SIM mode was used to determine and quantify peak abundance the FAME. Thus, the target and the qualifier ion abundances were determined by injection of fatty acid standards after derivatization supplied by Sigma-Aldrich (Sigma-Aldrich, USA) under the same chromatographic conditions described above using full-scan with the $\mathrm{m} / \mathrm{z}$ ratio ranging from 100 to 550 . Then, compounds were confirmed by their retention times, the identification of target and two qualifier ions, and the determination of qualifier to target ion ratios. Retention times must be within $\pm 0.2 \mathrm{~min}$ of the expected time and qualifier to target ion ratios within a $20 \%$ range for positive confirmation. Peak abundance was obtained by integration with ChemStation software (Agilent Technologies, UK) and expressed as the percentage of each fatty acid in comparison to the total area of all fatty acids present in the sample. Full scan mode was run at the same time to have further confirmation of each fatty with the inbuilt NIST database.

\subsection{Statistical analysis}

All analyses were performed using three independent repetitions, with each repetition produced from a different fish fillet and different production batch. The normality of the results and homogeneity of variances was established using Saphiro-Wilk and Levene's test respectively $(P<0.05)$. The significance of differences was established by one-way ANOVA with Tukey post-hoc test $(P<0.05)$. The significance of differences was established separately for nigiri and hosomaki samples. The statistical analysis was performed using STATISTICA v.12.0 software (StatSoft, Tulsa, USA). 
Table 3

Changes in TBA index in treated and untreated nigiri and hosomaki samples during storage $[\mathrm{mg} / \mathrm{kg}]$.

\begin{tabular}{|c|c|c|c|c|c|}
\hline & Day 1 & Day 3 & Day 5 & Day 8 & Day 11 \\
\hline Nigiri control & $1.29^{\mathrm{aA}} \pm 0.44$ & $0.94^{\mathrm{aA}} \pm 0.10$ & $1.23^{\mathrm{aA}} \pm 0.32$ & $0.75^{\mathrm{aA}} \pm 0.35$ & $\mathrm{n} / \mathrm{a}$ \\
\hline Nigiri $70 \mathrm{kV}$ & $1.69^{\mathrm{aA}} \pm 0.17$ & $1.71^{\mathrm{aB}} \pm 0.02$ & $1.94^{\mathrm{aB}} \pm 0.12$ & $1.52^{\mathrm{aA}} \pm 0.59$ & $\mathrm{n} / \mathrm{a}$ \\
\hline Nigiri $80 \mathrm{kV}$ & $2.03^{\mathrm{aA}} \pm 0.33$ & $2.00^{\mathrm{aC}} \pm 0.10$ & $2.16^{\mathrm{aB}} \pm 0.26$ & $1.83^{\mathrm{aA}} \pm 0.20$ & $\mathrm{n} / \mathrm{a}$ \\
\hline Hosomaki control & $2.42^{\mathrm{abA}} \pm 0.03$ & $1.78^{\mathrm{abA}} \pm 0.37$ & $1.58^{\mathrm{aA}} \pm 0.24$ & $2.60^{\mathrm{abA}} \pm 0.30$ & $3.12^{\mathrm{bA}} \pm 0.70$ \\
\hline Hosomaki 70 kV & $3.12^{\mathrm{aB}} \pm 0.10$ & $2.64^{\mathrm{aB}} \pm 0.25$ & $2.40^{\mathrm{aA}} \pm 0.72$ & $3.12^{\mathrm{aA}} \pm 0.41$ & $2.85^{\mathrm{aA}} \pm 0.36$ \\
\hline Hosomaki $80 \mathrm{kV}$ & $2.92^{\mathrm{aB}} \pm 0.20$ & $2.40^{\mathrm{aAB}} \pm 0.07$ & $3.11^{\mathrm{aB}} \pm 0.69$ & $3.20^{\mathrm{aA}} \pm 0.14$ & $3.62^{\mathrm{aA}} \pm 0.50$ \\
\hline
\end{tabular}

a,b,c,d - different lowercase in a row indicate differences between days of storage within the same group $(P<0.05)$.

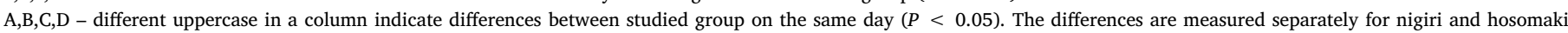
groups.

$\mathrm{n} / \mathrm{a}$ - analysis was not performed due to high microbiological spoilage of the samples (Table 1).

Table 4

The effect of non-thermal plasma treatment on the most abundant fatty acids of sushi $[\%$ of fat $]$ measured on day 1 of storage at $4{ }^{\circ} \mathrm{C}$.

\begin{tabular}{|c|c|c|c|c|c|c|c|c|c|c|}
\hline \multirow[b]{2}{*}{ Fatty acid } & \multirow[b]{2}{*}{ Fatty acid name } & \multicolumn{2}{|c|}{ Nigiri control } & \multicolumn{2}{|c|}{ Nigiri $70 \mathrm{kV}$} & \multicolumn{2}{|c|}{ Nigiri 80 kV } & \multirow{2}{*}{$\begin{array}{l}\text { Hosomaki control } \\
\mathrm{SD}\end{array}$} & \multirow{2}{*}{$\begin{array}{l}\text { Hosomaki } 70 \mathrm{kV} \\
\text { Mean }\end{array}$} & \multirow{2}{*}{$\begin{array}{l}\text { Hosomaki } 80 \mathrm{kV} \\
\mathrm{SD}\end{array}$} \\
\hline & & Mean & SD & Mean & Mean & SD & Mean & & & \\
\hline C14:0 & Myristic acid & $1.37^{\mathrm{a}}$ & 0.73 & $1.80^{\mathrm{a}}$ & $1.52^{\mathrm{a}}$ & 0.22 & $1.47^{\mathrm{a}}$ & 0.18 & $1.47^{\mathrm{a}}$ & 1.97 \\
\hline $\mathrm{C} 16: 0$ & Palmitic acid & $18.33^{\mathrm{a}}$ & 4.80 & $15.76^{\mathrm{a}}$ & $20.54^{\mathrm{a}}$ & 3.15 & $21.00^{\mathrm{a}}$ & 2.98 & $22.52^{\mathrm{a}}$ & 20.14 \\
\hline C18:0 & Stearic acid & $3.45^{\mathrm{a}}$ & 2.22 & $2.63^{\mathrm{a}}$ & $2.94^{\mathrm{a}}$ & 0.75 & $2.94^{\mathrm{a}}$ & 0.48 & $3.06^{\mathrm{a}}$ & 3.36 \\
\hline C18:1 & Oleic acid & $29.85^{\mathrm{a}}$ & 4.26 & $31.65^{\mathrm{a}}$ & $28.70^{\mathrm{a}}$ & 5.16 & $30.78^{\mathrm{a}}$ & 4.39 & $29.06^{\mathrm{a}}$ & 6.21 \\
\hline C18:2 & Linoleic acid & $19.57^{\mathrm{a}}$ & 7.74 & $16.48^{\mathrm{a}}$ & $18.66^{\mathrm{a}}$ & 1.93 & $16.35^{\mathrm{a}}$ & 2.28 & $17.76^{\mathrm{a}}$ & 2.11 \\
\hline C18:3 & $\alpha$-linolenic acid & $4.02^{\mathrm{a}}$ & 0.90 & $4.47^{\mathrm{a}}$ & $4.01^{\mathrm{a}}$ & 0.52 & $3.96^{\mathrm{a}}$ & 0.46 & $4.21^{\mathrm{a}}$ & 1.25 \\
\hline C20:5 & Eicosapentaenoic acid & $3.24^{\mathrm{a}}$ & 0.79 & $6.27^{\mathrm{a}}$ & $11.30^{\mathrm{a}}$ & 3.10 & $12.29^{\mathrm{a}}$ & 3.99 & $10.69^{\mathrm{a}}$ & 3.86 \\
\hline $\mathrm{C} 22: 6$ & Docosahexaenoic acid & $12.18^{\mathrm{a}}$ & 4.57 & $14.22^{\mathrm{a}}$ & $15.56^{\mathrm{a}}$ & 2.88 & $17.36^{\mathrm{a}}$ & 3.95 & $17.40^{\mathrm{a}}$ & 5.02 \\
\hline
\end{tabular}

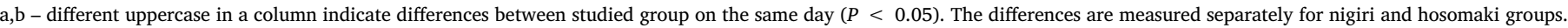

\section{Results and discussion}

\subsection{The effect of non-thermal plasma treatment on microbiological quality of sushi}

The effect of NTP treatment on the microbiological quality of stored sushi samples is shown in Table 1. Throughout the storage period the hosomaki samples (both treated and untreated) had significantly lower TVC than the nigiri (data not shown). The initial contamination of nigiri samples ranged from $4.83-5.96 \mathrm{log} \mathrm{cfu} / \mathrm{g}$ and reached 8.99-9.16 log cfu/g at day 11. Meanwhile the initial contamination of hosomaki ranged from $4.38-4.9 \log \mathrm{cfu} / \mathrm{g}$ and reached 4.71-6.22 $\log \mathrm{cfu} / \mathrm{g}$ at the last day of storage. These differences are to be expected, since nigiri contained higher proportions of raw fish than hosomaki. Although the initial contamination of nigiri samples might seem high, higher results have been reported for the bacterial concentration of fresh nigiri and hosomaki produced in restaurants (Atanassova, Reich, \& Klein, 2008; Leisner et al., 2014).

There was no statistically significant difference in the TVC between the treated and untreated nigiri and hosomaki samples throughout the whole storage period. Moreover there were not statistically significant differences between samples treated with 70 and $80 \mathrm{kV}$ of discreet voltage throughout the whole storage period. While not significant the highest inhibition of bacterial concentration in the nigiri samples was found on day 1 of storage, with the treated samples found to have a 1 $\log$ lower cfu/g than the control. From day 3 however, the TVC for all nigiri samples was similar, with differences in the bacterial concentration $<1 \log \mathrm{cfu} / \mathrm{g}$. The differences in TVC between hosomaki samples treated with NTP were $<1 \log \mathrm{cfu} / \mathrm{g}$ during the first 3 days of storage but reached $\sim 1.5 \log \mathrm{cfu} / \mathrm{g}$ at the last day of storage.

The recommended limit for TVC in ready-to-eat food products, such as sushi, is $10^{6} \mathrm{cfu} / \mathrm{g}$ (ANZFA, 2001; Gilbert et al., 2000). According to these guidelines the studied nigiri samples were not fit for consumption on day 3 and the treatment with NTP failed to improve the shelf-life of nigiri samples. The treated nigiri samples, increased significantly by approximately $1.5 \log \mathrm{cfu} / \mathrm{g}$ at the beginning of storage period, from day 1 to day 3 , meanwhile the increase in untreated nigiri samples at the same time period was not significant (approx $0.8 \log \mathrm{cfu} / \mathrm{g}$ ). Therefore even though the initial bacterial concentration of the treated samples was lower, the resulting increase during the first days of storage resulted in similar contamination of above $6 \mathrm{log} \mathrm{cfu} / \mathrm{g}$ for all treated samples, and resulted in no shelf-life extension.

On the other hand the treated hosomaki samples were still fit for consumption at the last day of storage, while the untreated samples exceeded the guidelines on day 8 .

Kim, Puligundla, and Mok (2015), who used corona discharge plasma jet system to treat squid shreds using NTP and reported a $2 \log \mathrm{cfu} / \mathrm{g}$ reduction in aerobic bacteria counts after $3 \mathrm{~min}$ of treatment, with a D-value of $1.47 \mathrm{~min}$. The treatment was also effective in reducing the counts of marine bacteria, yeasts and moulds and Staphylococcus aureus. Albertos et al. (2017) treated fresh mackerel fillets with NTP using a DBD system operating at 70 and $80 \mathrm{kV}$ for 1,3 and $5 \mathrm{~min}$. Although none of the treatments significantly affected the total aerobic mesophilic counts, the treatment was effective in reducing bacterial concentration of psychrotrophic bacteria, lactic acid bacteria and Pseudomonas, with $80 \mathrm{kV}$ for 3 and 5 min treatments being the most effective. According to Rød, Hansen, Leipold, and Knøchel (2012) ozone concentrations during NTP treatment in atmospheric pressure increases for first $40 \mathrm{~s}$ after which it remains on a constant level. Surprisingly however, the higher power was used, the lower maximum ozone concentrations were acquired and consequently lower reduction in Listeria innocua was observed. This was attributed to surface changes in the plastic bag, used as a container. Due to the fact, that ozone is present inside the sealed container for additional minutes after the end of the plasma treatment, they found that conducting a few short treatment times with $10 \mathrm{~min}$ intervals between the treatments was more effective than a single dose treatment for a longer period (Rød et al., 2012). Therefore, it is possible that using few shorter treatments with time intervals between each treatment could have been more effective in inhibition of bacterial growth in studied nigiri and hosomaki samples. It should be noted however, that such prolonged exposure to ozone and other RS might increase the oxidation thus causing the 
deterioration in the quality of the final product.

It is surprising, that NTP treatment was more effective in increasing the shelf-life of hosomaki and not the nigiri samples. Since NTP treatment mostly affects the microorganisms located on the surface of the product, and given that raw fish is the likely primary cause of the high bacterial concentration, it was expected that nigiri samples would be more affected, due to higher raw fish surface which is exposed to contact with formed RS than hosomaki. On the other hand, NTP treatment is known to affect the composition of starch, with various RS causing the degradation of amylose and formation of new compounds which in turn reduces the $\mathrm{pH}$ (F. Zhu, 2017). The $\mathrm{pH}$ of sushi rice is usually close to 4.3 due to the addition of rice vinegar (Adams et al., 1994) and the NTP treatment might cause a further drop in $\mathrm{pH}$ (Schluiter et al., 2013). Since the acidified rice lowers the $\mathrm{pH}$ of the fish piece through direct contact (Lorentzen, Wesmajervi Breiland, Cooper, \& Herland, 2012), it might affect the TVC of the sushi samples, especially for hosomaki, in which a greater surface area is in contact with the rice and the whole roll is more tightly squeezed.

\subsection{Changes in protein and moisture content}

Changes in the quality and sensory attributes of stored rice are one of the main problems faced by sushi industry, which affects the product's shelf-life. Such changes are mostly related to the process of rice retrogradation and moisture loss, resulting in texture changes, mostly hardness, which can affect the sensory scores of the product deeming it not suitable for consumption (Meullenet, Marks, Hankins, Griffin, \& Daniels, 2000). Since plasma treatment can reduce the moisture content of starch (Zhu, 2017) and thus affect the sensory quality of sushi, the changes in moisture content of both nigiri and hosomaki was measured (Table 2). There were no significant differences in the moisture content between the treated and untreated samples throughout the storage period, which suggests that in case of sushi, NTP treatment did not cause moisture loss. A second factor for rice sensory quality is starch retrogradation. It has been reported that plasma treatment can reduce the degree of crystallinity of starch molecules along with the molecular degradation of starch (Mir, Shah, \& Mir, 2016); besides, NTP can reduce starch retrogradation rate and improve texture parameters of stored rice (Thirumdas, Kadam, \& Annapure, 2017; Zhang, Chen, Li, Li, \& Zhang, 2015). This fact, together the absence of moisture loss, suggests that NTP could be a possible method to improve sensory scores of stored sushi rice, however more research on this subject should be performed in order to confirm this.

Neither NTP treatment conditions nor the storage time affected the overall protein content of the sushi samples. This was not surprising since usually the changes in proteins are associated with moisture loss. On the other hand Matan, Puangjinda, Phothisuwan, and Nisoa (2015) found that NTP significantly increased the content of crude protein, fat, carbohydrates and fiber, while not affecting the moisture content in fresh-cut dragon fruit. Moreover since NTP is a surface treatment, it can cause changes in the proteins on the surface of the product, which will not be shown by the crude protein content analysis. The RS created by plasma treatment can react with proteins in both rice and fish. For example as shown by Albertos et al. (2017) NTP treatment affected the myofibrillar network of fish meat, significantly reducing the amount of water immobilised in such matrix and increasing the free water content, while Segat, Misra, Cullen, and Innocente (2015) reported the changes in structural composition of whey protein isolate, which improved foaming and emulsifying properties of the protein isolate.

\subsection{The effect of NTP treatment on lipid oxidation and fatty acids composition of sushi}

NTP treatment increased the TBARS content of both nigiri and hosomaki samples, with hosomaki containing higher levels of TBA index than nigiri (Table 3). Untreated nigiri contained significantly lower TBA index on day 3 and 5 of storage, while untreated hosomaki had a significantly lower levels of TBA index on day 1, 3 and 5 of storage. After day 5 the differences in TBA index for both nigiri and hosomaki were statistically insignificant.

Hosomaki generally had higher TBA index than nigiri samples. This might be due to the fact that the surface area to weight of sample ratio is greater than in nigiri. Moreover hosomaki are wrapped in nori sheet, which contains unsaturated fatty acids and might be more prone to oxidation induced by NTP treatment (Dawczynski, Schubert, \& Jahreis, 2007).

As established by Connell (1995), a TBA index of $2 \mathrm{mg} / \mathrm{kg}$ and above for fish muscle is associated with spoilage and decreases in sensory attributes. Research performed on rainbow trout by Raeisi, Quek, Ojagh, and Alishahi (2016) showed similar pattern, where the fish samples were rejected by the sensory panel when the TBA index increased beyond $2 \mathrm{mg} / \mathrm{kg}$.

Nigiri treated with $80 \mathrm{kV}$ exceeded the proposed limit at the beginning of the storage period, while untreated and treated with $70 \mathrm{kV}$ remained below the $2 \mathrm{mg} / \mathrm{kg}$ threshold during the whole storage period. The initial TBA index of hosomaki ranged from $2.42-3.12 \mathrm{mg} /$ $\mathrm{kg}$, therefore the hosomaki samples, both treated and untreated, exceeded the $2 \mathrm{mg} / \mathrm{kg}$ limit on the first day of storage.

The TBA index of all samples remained at a constant level with no statistically significant differences between days of storage observed with the exception of untreated hosomaki, which increased significantly at the last days of storage.

The analysis of fatty acids composition showed that the most abundant fatty acids in sushi were palmitic acid (C16:0); oleic acid (C18:1, n-9); linoleic acid (C18:2, n-6) eicosapentanoic acid (EPA, C20:5, n-3) and docosahexanoic acid (DHA, C22:6 n-3) (Table 4). However, no significant differences in the content of each fatty acid were found between the treated and untreated samples for both sushi products. Therefore the NTP treatment and resulting increased oxidation, observed through TBA index analysis, did not affect the fatty acids composition as measured for these sushi samples.

As in case of protein, the surface treatment with NTP might result in increased oxidation of surface fatty acids, which was not shown through the analysis of the overall fatty acids composition found in the product. The significant increase in TBA index with no significant differences in fatty acids composition suggests that TBARS could be formed from other non-lipid molecules such as proteins, nucleic acids or carbohydrates (Janero, 1990).

The fatty acids composition of the studied sushi samples differed from the fatty acids composition usually found in salmon (Bell, Tocher, Henderson, Dick, \& Crampton, 2003; Torstensen, Lie, \& Frøyland, 2000). Nori might affect the content of EPA, since it usually contains high levels of this fatty acids (Dawczynski et al., 2007). This would also explain the difference in the EPA content between nigiri and hosomaki samples. Moreover rice contains high levels of palmitic, oleic and linoleic acid (Zhou, Blanchard, Helliwell, \& Robards, 2003), which could also explain the higher levels of these fatty acids in sushi over that of salmon.

\section{Conclusions}

Non-thermal plasma treatment seemed to have some influence on microbiological quality of sushi, however the effect was limited. Nevertheless, both 70 and $80 \mathrm{kV}$ treatments for $5 \mathrm{~min}$ extended the shelf-life of the stored hosomaki product by an additional 4 days in terms of microbiological spoilage. Moreover the plasma treatment did not affected moisture content of the sushi samples, and did not alter the fatty acids composition even though the TBA analysis showed an increase in oxidation processes.

Future research should focus on the effect of non-thermal plasma on sushi stored in modified atmosphere and the effect on rice retrogradation and sensory evaluation in order to fully assess the 
effectiveness and possibility of implementing this processing method for the sushi industry.

\section{Conflict of interest}

The authors declare that there is no interest or relationship, financial or otherwise that might be perceived as influencing an author's objectivity.

\section{References}

Adams, A. M., Leja, L. L., Jinneman, K., Beeh, J., Yuen, G. A., \& Wekell, M. M. (1994). Anisakid parasites, Staphylococcus aureus and Bacillus cereus in sushi and sashimi from Seattle area restaurants. Journal of Food Protection, 57(4), 311-317.

Albertos, I., Martin-Diana, A. B., Cullen, P. J., Tiwari, B. K., Ojha, S. K., Bourke, P., ... Rico, D. (2017). Effects of dielectric barrier discharge (DBD) generated plasma on microbial reduction and quality parameters of fresh mackerel (Scomber scombrus) fillets. Innovative Food Science \& Emerging Technologies, 44, 117-122.

Altintzoglou, T., Heide, M., Wien, A. H., \& Honkanen, P. (2016). Traditional sushi for modern consumers: A comparison between sushi consumption behavior in Japan and Norway. Journal of Food Products Marketing, 22(6), 717-732.

ANZFA (2001). Guidelines for the microbiological examination of ready - to - eat foods. The Australia New Zealand Food Authority.

AOAC (2007). Official methods of analysis of AOAC international (18th ed.). .

Atanassova, V., Reich, F., \& Klein, G. (2008). Microbiological quality of sushi from sushi bars and retailers. Journal of Food Protection, 71(4), 860-864.

Bell, J. G., Tocher, D. R., Henderson, R. J., Dick, J. R., \& Crampton, V. O. (2003). Altered fatty acid compositions in Atlantic Salmon (Salmo salar) fed diets containing linseed and rapeseed oils can be partially restored by a subsequent fish oil finishing diet. The Journal of Nutrition, 133(9), 2793-2801.

Bligh, E. G., \& Dyer, W. J. (1959). A rapid method of total lipid extraction and purification. Canadian Journal of Biochemistry and Physiology, 37(8), 911-917.

Boudam, M. K., Moisan, M., Saoudi, B., Popovici, C., Gherardi, N., \& Massines, F. (2006). Bacterial spore inactivation by atmospheric-pressure plasmas in the presence or absence of UV photons as obtained with the same gas mixture. Journal of Physics D: Applied Physics, 39(16), 3494.

Connell, J. J. (1995). Control of fish quality (4th ed.). London: Wiley-Blackwell.

Dawczynski, C., Schubert, R., \& Jahreis, G. (2007). Amino acids, fatty acids, and dietary fibre in edible seaweed products. Food Chemistry, 103(3), 891-899.

Don, L. Z. (1997). The impact of consumer demands and trends on food processing. Emerging Infectious Diseases, 3(4), 467.

Ehlbeck, J., Schnabel, U., Polak, M., Winter, J., von TH, W., Brandenburg, R., ... Weltmann, K. D. (2011). Low temperature atmospheric pressure plasma sources for microbial decontamination. Journal of Physics D: Applied Physics, 44(1), 013002.

Fridman, G., Brooks, A. D., Balasubramanian, M., Fridman, A., Gutsol, A., Vasilets, V. N., ... Friedman, G. (2007). Comparison of direct and indirect effects of non-therma atmospheric-pressure plasma on bacteria. Plasma Processes and Polymers, 4(4), 370-375.

Fu, Z., Chen, J., Luo, S.-J., Liu, C.-M., \& Liu, W. (2015). Effect of food additives on starch retrogradation: A review. Starch-Starke, 67(1-2), 69-78.

Gilbert, R. J., de Louvois, J., Donovan, T., Little, C., Nye, K., Ribeiro, C. D., ... Bolton, F. J. (2000). Guidelines for the microbiological quality of some ready-to-eat foods sampled at the point of sale. PHLS Advisory Committee for Food and Dairy Products. Communicable Disease and Public Health, 3(3), 163-167.

Ichihara, K., Shibahara, A., Yamamoto, K., \& Nakayama, T. (1996). An improved method for rapid analysis of the fatty acids of glycerolipids. Lipids, 31, 535-539.

Jacobo-Velázquez, D. A., \& Hernández-Brenes, C. (2010). Biochemical changes during the storage of high hydrostatic pressure processed avocado paste. Journal of Food Science, 75(6), S264-S270.

Janero, D. R. (1990). Malondialdehyde and thiobarbituric acid-reactivity as diagnostic indices of lipid peroxidation and peroxidative tissue injury. Free Radical Biology and Medicine, 9(6), 515-540.

Kim, J.-W., Puligundla, P., \& Mok, C. (2015). Microbial decontamination of dried laver using corona discharge plasma jet (CDPJ). Journal of Food Engineering, 161, 24-32.

Kwak, H. S., Kim, M., \& Jeong, Y. (2015). Physicochemical properties and determination of key instrumental quality measurement parameters of frozen-cooked Rice by correlating consumer acceptance. Journal of Food Quality, 38(3), 192-200.

Leisner, J. J., Lund, T. B., Frandsen, E. A., Andersen, N. B. E., Fredslund, L., Nguyen, V. P. T., \& Kristiansen, T. (2014). What consumers expect from food control and what they get - A case study of the microbial quality of sushi bars in Denmark. Food Control, 45,
76-80.

López-Malo, A., Palou, E., Barbosa-Cánovas, G. V., Welti-Chanes, J., \& Swanson, B. G. (1998). Polyphenoloxidase activity and color changes during storage of high hydrostatic pressure treated avocado puree. Food Research International, 31(8), $549-556$.

Lorentzen, G., Wesmajervi Breiland, M. S., Cooper, M., \& Herland, H. (2012). Viability of listeria monocytogenes in an experimental model of nigiri sushi of halibut (Hippoglossus hippoglossus) and salmon (Salmo salar). Food Control, 25(1), 245-248.

Matan, N., Puangjinda, K., Phothisuwan, S., \& Nisoa, M. (2015). Combined antibacterial activity of green tea extract with atmospheric radio-frequency plasma against pathogens on fresh-cut dragon fruit. Food Control, 50, 291-296.

Meullenet, J. F., Marks, B. P., Hankins, J. A., Griffin, V. K., \& Daniels, M. J. (2000). Sensory quality of cooked long-grain rice as affected by rough rice moisture content, storage temperature, and storage duration. Cereal Chemistry, 77(2), 259-263.

Mir, S. A., Shah, M. A., \& Mir, M. M. (2016). Understanding the role of plasma technology in food industry. Food and Bioprocess Technology, 9(5), 734-750.

Misra, N. N., Pankaj, S. K., Walsh, T., O'Regan, F., Bourke, P., \& Cullen, P. J. (2014). Inpackage nonthermal plasma degradation of pesticides on fresh produce. Journal of Hazardous Materials, 271, 33-40.

Misra, N. N., Tiwari, B. K., Raghavarao, K. S. M. S., \& Cullen, P. J. (2011). Nonthermal plasma inactivation of food-borne pathogens. Food Engineering Reviews, 3(3), 159-170.

Moreau, M., Orange, N., \& Feuilloley, M. G. J. (2008). Non-thermal plasma technologies: New tools for bio-decontamination. Biotechnology Advances, 26(6), 610-617.

NSC (2015). Seafood study 2014: Insight and outlook: How the Germans eat fish. Norwegian Seafood Council.

Pikul, J., Leszczynski, D. E., \& Kummerow, F. A. (1989). Evaluation of three modified TBA methods for measuring lipid oxidation in chicken meat. Journal of Agricultural and Food Chemistry, 37(5), 1309-1313.

Raeisi, S., Quek, S. Y., Ojagh, S. M., \& Alishahi, A. R. (2016). Effects of cumin (Cuminum cyminum L.) seed and wild mint (Mentha longifolia L.) leaf extracts on the shelf life and quality of rainbow trout (Oncorhynchus mykiss) fillets stored at $4{ }^{\circ} \mathrm{C} \pm 1$. Journal of Food Safety, 36(2), 271-281.

Rød, S. K., Hansen, F., Leipold, F., \& Knøchel, S. (2012). Cold atmospheric pressure plasma treatment of ready-to-eat meat: Inactivation of Listeria innocua and changes in product quality. Food Microbiology, 30(1), 233-238.

Schlüter, O., Ehlbeck, J., Hertel, C., Habermeyer, M., Roth, A., Engel, K.-H., ... Eisenbrand, G. (2013). Opinion on the use of plasma processes for treatment of foods. Molecular Nutrition \& Food Research, 57(5), 920-927.

Scholtz, V., Pazlarova, J., Souskova, H., Khun, J., \& Julak, J. (2015). Nonthermal plasma - A tool for decontamination and disinfection. Biotechnology Advances, 33(6, Part 2), 1108-1119.

Segat, A., Misra, N. N., Cullen, P. J., \& Innocente, N. (2015). Atmospheric pressure cold plasma (ACP) treatment of whey protein isolate model solution. Innovative Food Science \& Emerging Technologies, 29, 247-254.

Sequeira-Munoz, A., Chevalier, D., LeBail, A., Ramaswamy, H. S., \& Simpson, B. K. (2006). Physicochemical changes induced in carp (Cyprinus carpio) fillets by high pressure processing at low temperature. Innovative Food Science \& Emerging Technologies, 7(1-2), 13-18.

Steffen, H., Duerst, M., \& Rice, R. G. (2010). User experiences with ozone, electrolytic water (active water) and UV-C light (Ventafresh technology) in production processes and for hygiene maintenance in a Swiss sushi factory. Ozone: Science \& Engineering, 32(1), 71-78.

Thirumdas, R., Kadam, D., \& Annapure, U. S. (2017). Cold plasma: An alternative technology for the starch modification. Food Biophysics, 12(1), 129-139.

Torstensen, B. E., Lie, Ø., \& Frøyland, L. (2000). Lipid metabolism and tissue composition in Atlantic salmon (Salmo salar L.) -Effects of capelin oil, palm oil, and oleic acidenriched sunflower oil as dietary lipid sources. Lipids, 35(6), 653-664.

Van Durme, J., Nikiforov, A., Vandamme, J., Leys, C., \& De Winne, A. (2014). Accelerated lipid oxidation using non-thermal plasma technology: Evaluation of volatile compounds. Food Research International, 62, 868-876.

Wang, S., Li, C., Copeland, L., Niu, Q., \& Wang, S. (2015). Starch retrogradation: A comprehensive review. Comprehensive Reviews in Food Science and Food Safety, 14(5), 568-585.

Zhang, B., Chen, L., Li, X., Li, L., \& Zhang, H. (2015). Understanding the multi-scale structure and functional properties of starch modulated by glow-plasma: A structurefunctionality relationship. Food Hydrocolloids, 50(Supplement C), 228-236.

Zhou, Z., Blanchard, C., Helliwell, S., \& Robards, K. (2003). Fatty acid composition of three rice varieties following storage. Journal of Cereal Science, 37(3), 327-335.

Zhu, F. (2017). Plasma modification of starch. Food Chemistry, 232, 476-486.

Zhu, S., Ramaswamy, H. S., \& Simpson, B. K. (2004). Effect of high-pressure versus conventional thawing on color, drip loss and texture of Atlantic salmon frozen by different methods. LWT - Food Science and Technology, 37(3), 291-299. 